\title{
Pengembangan Perangkat Pembelajaran Kooperatif Tipe STAD untuk Meningkatan Motivasi Belajar Siswa Kelas VIII Pada Materi Faktorisasi Suku Aljabar
}

\author{
Darmanto Minggele ${ }^{1 *}$ \\ ${ }^{1}$ Program Pascasarjana Penelitian \& Evaluasi Pendidikan, Universitas Negeri Yogyakarta, Jl. \\ Colombo No.1, Karang Malang, Caturtunggal, Kec. Depok, Kabupaten Sleman, Daerah Istimewa \\ Yogyakarta 55281, Indonesia. \\ * Korespondensi Penulis. E-mail: darmantominggele.2018@student.uny.ac.id
}

\begin{abstract}
Abstrak
Penelitian ini bertujuan untuk menghasilkan perangkat pembelajaran kooperatif tipe STAD untuk meningkatkan motivasi belajar pada materi faktorisasi suku aljabar siswa kelas VIII. Prosedur pengembangan perangkat pembelajaran mengacu pada model pengembangan Four - $D$ yang terdiri dari 4 fase, yaitu: (1) Pendefinisian (Define), (2) Perencanaan (Design), (3) Pengembangan (Develop), (4) Penyebaran (Disseminate) namun ini tidak dilaksanakan. Subjek Penelitian siswa kelas VIII MTs N Sumber Bungur Pamekasan. Perangkat yang dikembangkan RPP, LKS, dan THB telah divalidasi dan diperoleh hasil dengan kategori baik, sedangkan setiap butir soal THB yang disusun telah memenuhi kriteria valid dengan nilai $>0,4$, reliabel dengan nilai 0,511 dan nilai sensitifitas setiap butir soal $\geq 0,342$, dan THB digunakan untuk mengetahui keefektifan pembelajaran kooperatif tipe STAD. Berdasarkan data yang yang diperoleh, hasil nilai observasi kemampuan guru dalam mengelola pembelajaran sebesar 3,6 pada pertemuan pertama, 4 pada pertemuan kedua, 3,8 pada pertemuan ketiga, dan 4 pada pertemuan keempat. Nilai tersebut masuk dalam kategori baik. Aktivitas siswa pada setiap pertemuan tergolong dalam kategori efektif. Respons siswa positif yang diketahui dari jumlah siswa yang memberikan respons positif $\geq 80 \%$ untuk setiap aspek. Ketuntasan belajar klasikal telah tercapai karena $\geq 80 \%$ siswa dalam kelas mendapatkan nilai lebih dari KKM yang telah ditentukan yaitu 75. Dari analisis deskriptif yang dilakukan untuk mengetahui perbandingan peningkatan ( gain) motivasi belajar siswa sebelum dan sesudah perlakuan antara kelas eksperimen dan kelas kontrol, diperoleh skor peningkatan (gain) motivasi belajar untuk kelompok eksperimen lebih besar dari kelas kontrol yaitu 0,41 (kategori sedang) pada kelas eksperimen dan 0,18 (kategori rendah) pada kelas kontrol. Hal ini menunjukkan bahwa pembelajaran kooperatif tipe STAD lebih baik dari pembelajaran konvensional.
\end{abstract}

Kata Kunci: Pengembangan Perangkat, Pembelajaran Kooperatif Tipe STAD, Meningkatkan Motivasi Belajar, Materi Faktorisasi Suku Aljabar

\section{Development of Cooperative Learning Type STAD Tool to Increase Student Learning Motivation in Class VIII on Factorization Material of the Algebra Tribe}

\begin{abstract}
This study is aimed to produce STAD type cooperative learning set to increase learning motivation on algebra term factorization material for eighth grade students. The procedure of learning set development refers to four-D development model that consist of four phases, those are: (1) Definition, (2) Design, (3) Development, (4) Dissemination, yet, it is not be done. Subject of the study are eighth grade students of MTs N Sumber Bungur Pamekasan. Learning sets to be developed are lesson plans (RPP), Students' work sheets (LKS), learning outcome test (THB) which have been validated and obtained result with good category, whereas every learning outcome test (THB) question items arranged have fulfilled valid category with value $>0.4$, reliable with value 0.511 and sensitivity value in every question items $\geq 0.342$ learning outcome test (THB) used to know the effectiveness of STAD type cooperative learning.Based on obtained data, observation value results of teacher's ability to manage learning is 3.6 on the first meeting, 4 on the second meeting, 3.8 on the third meeting, ad 4
\end{abstract}


on the fourth meeting. The results included on good category. Students' activities on every meeting are classified on effective category. Students' responses are positive known from number of students who give positive response $\geq 80 \%$ for every aspect. Classical learning completeness has been achieved because $\geq 80 \%$ of students in the class get score more than minimal completeness criteria (KKM) that have set (75). From descriptive analysis that had been done to know the ratio of the increasing of students' learning motivation before and after treatment between experiment class and control class, obtained increasing score for learning motivation on experiment group is bigger than class control: 0.41 (medium category) on experiment class and 0.18 (low category) on control class. It shows that STAD type cooperative learning is better than conventional learning. Questionnaire responses of students in the first cycle there were 15 items with an overall percentage of $77.36 \%$ and in the second cycle $81.53 \%$.

Keywords: Sets Development, STAD Type Cooperative Learning, Increasing Learning Motivation, Algebra Term Factorization Materials

\section{PENDAHULUAN}

Perkembangan ilmu pengetahuan dan teknologi (IPTEK) yang semakin pesat telah membawa implikasi perubahan dalam dunia pendidikan. Segala perubahan yang terjadi dalam kehidupan masyarakat membuat dunia pendidikan terus menyesuaikan diri, berubah sesuai dengan perkembangan jaman. ${ }^{1}$ Dunia pendidikan sangat terkait dengan siswa sebagai peserta didik yang merupakan subjek utama dalam pendidikan. Siswa harus dibekali dengan pengetahuan, keterampilan, dan sikap yang memungkinkannya untuk mandiri, sehingga dapat memberikan kontribusi yang bermanfaat bagi pembangunan bangsa dan negara. ${ }^{2}$ Dalam UU No. 20 Pasal 2 dan 3 tahun 2003 tentang Sistem Pendidikan Nasional disebutkan bahwa:

"Pendidikan Nasional berdasarkan Pancasila dan Undang-Undang Dasar Negara Republik Indonesia Tahun 1945 berfungsi mengembangkan kemampuan dan membentuk watak serta peradaban bangsa yang bermartabat dalam rangka mencerdaskan kehidupan bangsa, bertujuan untuk mengembangkan potensi peserta didik agar menjadi manusia yang beriman dan bertakwa kepada Tuhan Yang Maha Esa, berakhlak mulia, sehat, berilmu, cakap, kreatif, mandiri, dan menjadi warga negara yang demokratis serta bertanggung jawab". 3

Pendidikan adalah salah satu bentuk perwujudan kebudayaan manusia yang dinamis dan sarat perkembangan. Oleh karena itu, perubahan atau perkembangan pendidikan adalah hal yang memang seharusnya terjadi sejalan dengan perubahan budaya kehidupan. Perubahan dalam arti perbaikan pendidikan pada semua tingkat perlu terus menerus dilakukan sebagai antisipasi kepentingan masa depan dan tuntutan masyarakat modern. ${ }^{4}$ Pendidikan yang mampu mendukung pembangunan di masa mendatang adalah pendidikan yang mampu mengembangkan potensi peserta didik, sehingga yang bersangkutan mampu menghadapi dan memecahkan problema kehidupan yang dihadapinya.

Hasil studi menyebutkan bahwa meski adanya peningkatan mutu pendidikan yang cukup menggembirakan, namun pembelajaran dan pemahaman siswa di tingkat dasar dan menengah pada beberapa materi pelajaran menunjukkan hasil yang kurang memuaskan. Pembelajaran konsep cenderung abstrak dan dengan metode ceramah, sehingga konsep-konsep akademik kurang bisa atau sulit dipahami (Amri, 2013). Sementara itu, kebanyakan guru dalam mengajar masih kurang memperhatikan kemampuan berpikir siswa, atau dengan kata lain tidak melakukan pengajaran bermakna, metode yang

${ }^{1}$ K Kartianom and Heri Retnawati, "Why Are Their Mathematical Learning Achievements Differents? Re- Analysis TIMSS 2015 Data In Indonesia, Japan, and Turkey," International Journal on New Trends in Education and Their Implications 9, no. 2 (2018): 33-46.

${ }^{2}$ Heri Retnawati et al., “Teachers' Knowledge about Higher-Oeder Thinking Skills and Its Learning Strategy," Problems of Education in the 21st Century 76, no. 2 (2018).

${ }^{3}$ Presiden Republik Indonesia, "Undang-Undang Republik Indonesia Nomor 20 Tahun 2003 Tentang Sistem Pendidikan Nasional," Pub. L. No. 20, 79 (2003).

4 Sofan Amri, Pengembangan Dan Model Pembelajaran Dalam Kurikulum 2013 (Jakarta: Prestasi Pustaka, 2013). 
digunakan kurang bervariasi, dan sebagai akibat motivasi belajar siswa menjadi sulit ditumbuhkan dan pola belajar cenderung menghafal dan mekanistis. ${ }^{5}$

Dampak lain dari proses pembelajaran tersebut adalah siswa lebih sering "menonton" gurunya mengajar daripada memperhatikan guru mengajar. Sehingga guru yang "lucu" apalagi memberi nilai "murah" akan menjadi favorit para siswa. Kondisi ini perlu adanya perubahan dan pembaharuan, inovasi ataupun gerakan perubahan mindset ke arah pencapaian tujuan pendidikan pada umumnya dan khususnya tujuan pembelajaran. Pembelajaran matematika hendaknya lebih bervariasi metode maupun strateginya guna mengoptimalkan potensi siswa.

Tiro menyatakan matematika sebagai alat, dalam posisi ini matematika berfungsi sebagai wahana untuk mencapai tujuan pendidikan hal ini dapat dilihat dengan banyaknya contoh pemanfaatan matematika dalam menyelesaikan masalah praktis, dan juga dikatakan bahwa matematika sebagai metode berpikir, dalam hal ini matematika digunakan sebagai wahana untuk membentuk cara berpikir dan kepribadian peserta didik. ${ }^{6}$ Dari ciri matematika, kita dapat menunjukkan bahwa ada unsur-unsur yang diterima begitu saja tanpa dipersoalkan dari mana datangnya, begitu pula pernyataan yang disebut aksioma atau postulat yang kebenarannya diterima tanpa harus dijelaskan secara rasional.

Dari kedua peran matematika di atas diharapkan dapat membentuk kepribadian peserta didik. Di sekolah, matematika digunakan untuk membiasakan peserta didik untuk bernalar. ${ }^{7}$ Dengan menggunakan kurikulum matematika yang bagaimanapun juga, aspek penataan nalar perlu mendapat perhatian, sehingga proses yang terjadi tetap mengarahkan kepada tujuan pendidikan itu sendiri. Hal ini menjadi semakin penting karena masa depan akan diwarnai oleh persaingan yang semakin ketat.

Agar pembudayaan nalar dapat dicapai, penyajian matematika di sekolah, baik dalam proses pembelajaran maupun dalam sajian buku ajar perlu mengarahkan kepada penataan nalar peserta didik. Bahan ajar perlu dikelola sehingga lebih tajam menata nalar peserta didik. Hal ini berakibat kepada guru, bahwa mereka harus kreatif dalam melaksanakan pembelajaran. Guru tidak hanya meyelesaikan materi kurikulum, tetapi mencermati dan mengevaluasi ketercapaian tujuan yang ingin dicapai dengan kurikulum tersebut.

Apino menyatakan bahwa "setiap model pembelajaran mengarahkan kita ke dalam mendesain pembelajaran untuk membantu peserta didik sedemikian rupa sehingga tujuan pembelajaran tercapai". ${ }^{8}$ Berdasarkan hal ini perkembangan model pembelajaran terus mengalami perubahan dari model tradisional menuju model yang lebih modern. Sejalan dengan pendekatan konstruktivisme dalam pembelajaran, salah satu model pembelajaran yang banyak mendapat respons adalah model pembelajaran kooperatif.

Isjoni mengemukakan pembelajaran kooperatif atau cooperative learning berasal dari kata cooperative yang artinya mengerjakan sesuatu secara bersama-sama dengan saling membantu satu sama lainnya sebagai satu kelompok atau satu tim. ${ }^{9}$ Slavin mengemukakan bahwa pembelajaran kooperatif adalah suatu model pembelajaran dimana sistem belajar dan bekerja dalam kelompok-kelompok kecil yang berjumlah 4-6 orang secara kolaboratif sehingga dapat merangsang siswa lebih bergairah dalam belajar. ${ }^{10}$ Menurut Ibrahim pembelajaran kooperatif dapat membantu siswa memahami konsep-konsep sulit, menumbuhkan kemampuan bekerjasama, dan berfikir kritis. ${ }^{11}$ Dapat diartikan bahwa pembelajaran kooperatif adalah kegiatan yang berlangsung dalam lingkungan belajar sehingga siswa dalam kelompok kecil yang bersifat heterogen tadi dapat saling membantu satu sama lain untuk

5 Indra Kusuma Wijayanti and Heri Retnawati, "Pengembangan Bahan Ajar Dengan Pendekatan Kontekstual Model Pembelajaran Active Joyful Effective Leraning Pada Materi Segiempat Dan Segitiga Kelas VII Untuk Meningkatkan Kemampuan Komunikasi Matematis Siswa," Jurnal Pendidikan Matematika-S1 6, no. 7 (2017): 73-83.

${ }^{6}$ Muhammad Arif Tiro, Cara Efektif Belajar Matematika (Makassar: Andira Publisher, 2010).

${ }^{7}$ Retnawati et al., "Teachers' Knowledge about Higher-Oeder Thinking Skills and Its Learning Strategy."

${ }^{8}$ Ezi Apino, "Meningkatkan Toleransi Siswa Dalam Pembelajaran Matematika Melalui Penerapan Model Guided Discovery Setting Pembelajaran Kooperatif Tipe Think Pair Share,” 2016.

${ }^{9}$ H Isjoni, Cooperative Learning (Bandung: Alfabeta, 2009).

${ }^{10}$ Isjoni.

${ }^{11}$ Hasan Langgulung, Manusia Dan Pendidikan: Suatu Analisa Psikologi, Filsafat Dan Pendidikan (Al Husna Zikra, 1995). 
memahami konsep-konsep sulit, saling berbagi ide-ide dan bekerja secara kolaboratif dalam menyelesaikan tugas akademik.

Pembelajaran kooperatif merupakan salah satu alternatif dalam usaha memperbaiki kualitas pembelajaran matematika. Pembelajaran kooperatif dapat meningkatkan keaktifan siswa dan memungkinkan siswa untuk saling berinteraksi membantu siswa lain dalam mencapai tujuan pembelajaran. Pembelajaran kooperatif memungkinkan terjadinya interaksi pembelajaran dua arah yaitu guru ke siswa dan siswa ke guru, maupun multi arah yaitu guru ke siswa, siswa ke guru, dan siswa ke siswa. Bentuk-bentuk interaksi tersebut dapat berupa penjelasan, diskusi, pertanyaan, refleksi atau persetujuan.

Ada beberapa tipe pembelajaran kooperatif yang dikenal saat ini di antaranya adalah STAD. Menurut Slavin STAD merupakan salah satu model pembelajaran kooperatif yang paling sederhana dan merupakan model yang paling baik untuk permulaan bagi para guru yang baru menggunakan pendekatan kooperatif. ${ }^{12}$ STAD terdiri atas lima komponen utama presentasi kelas, tim, kuis, skor kemajuan individual, rekognisi tim. Dengan kata lain STAD terdiri atas sebuah siklus instruksi kegiatan regular, mulai dari guru menyampaikan materi kemudian siswa bekerja dengan lembar kegiatan dilanjutkan dengan siswa mengerjakan kuis secara individual dan kemudian skor tim dihitung berdasarkan skor kemajuan dan ada penghargaan untuk skor tertinggi sehingga hal ini dapat memotivasi siswa untuk ikut aktif berpartisipasi dalam pembelajaran.

Sejalan dengan komponen kooperatif tipe STAD ini Schunk mengemukakan bahwa motivasi sangat terkait dengan pembelajaran. Motivasi dan pembelajaran bisa saling mempengaruhi. Motivasi siswa bisa mempengaruhi apa dan bagaimana mereka belajar. ${ }^{13}$ Nur mengemukakan bahwa dengan keterlibatan siswa dalam proses pembelajaran akan mempengaruhi motivasi siswa itu sendiri dan dengan siswa yang termotivasi untuk belajar maka dia akan menggunakan proses kognitif yang lebih tinggi dalam mempelajari materi tertentu, sehingga siswa akan meyerap dan mengendapkan materi itu dengan lebih baik. ${ }^{14}$

Peneliti memilih pembelajaran kooperatif tipe STAD karena 1) memberi kesempatan yang lebih bagi siswa untuk dapat memahami materi dan berpartisipasi dalam pembelajaran sesuai dengan komponen STAD. 2) belum banyak diterapkan di SMP. Dengan demikian berdasarkan latar belakang yang telah dipaparkan tersebut, peneliti terdorong untuk melakukan penelitian yang lebih spesifik dengan judul "Pengembangan Perangkat Pembelajaran Kooperatif Tipe STAD Untuk Meningkatkan Motivasi Belajar Siswa Kelas VIII Pada Materi Faktorisasi Suku Aljabar". Oleh karena itu, tujuan dalam penelitian ini terdiri dari tiga macam, yaitu: Mendeskripsikan proses dan hasil pengembangan perangkat pembelajaran kooperatif tipe STAD yang baik pada materi faktorisasi suku aljabar kelas VIII. Mengetahui keefektifan pembelajaran kooperatif tipe STAD untuk mengajarkan materi faktorisasi suku aljabar kelas VIII. Membandingkan motivasi belajar siswa yang mengikuti pembelajaran kooperatif tipe STAD dengan siswa yang mengikuti pembelajaran konvensional pada materi faktorisasi suku aljabar.

Pembelajaran kooperatif tipe Student Teams Achievement Division (STAD) merupakan salah satu tipe pembelajaran kooperatif yang paling sederhana. Pembelajaran kooperatif tipe STAD tidak jauh berbeda dengan pembelajaran yang dilakukan oleh guru pada umumnya hanya saja pada pembelajaran kooperatif siswa bekerja secara kelompok untuk menuntaskan materi dan adanya penghargaan kelompok. Dalam STAD siswa dibagi menjadi beberapa kelompok yang beranggotakan 4-5 orang yang beragam kemampuan, jenis kelamin, dan sukunya.

Ide utama dari STAD menurut Nur adalah untuk memotivasi siswa saling memberi semangat dan membantu dalam menuntaskan keterampilan-keterampilan yang dipresentasikan guru. ${ }^{15} \mathrm{Hal}$ ini karena pada akhir pembelajaran dengan model pembelajaran kooperatif tipe STAD ini akan diberikan sebuah penghargaan atau hadiah, hadiah atau penghargaan akan diberikan kepada kelompok yang mampu melampaui skor awal tim. Dalam hal ini memacu siswa agar saling mendorong dan membantu satu sama lain untuk menguasai keterampilan yang diajarkan guru agar berhasil dalam menyelesaikan kuis yang

${ }^{12}$ Robert E Slavin, Psikologi Pendidikan Teori Dan Praktik (Jakarta: Indeks, 2011).

${ }^{13}$ Dale H Schunk, Learning Theories an Educational Perspective Sixth Edition (Pearson, 2012).

14 Moh Nur, "Pemotivasian Siswa Untuk Belajar" (Surabaya: University Press-Universitas Negeri Surabaya, 2001).

${ }^{15}$ Nur. 
akan dikerjakan secara individu (tanggung jawab tiap individu) namun skor yang diperoleh akan menjadi skor kelompok. Apabila siswa menginginkan kelompok mereka mendapat penghargaan, mereka harus membantu teman dalam satu kelompok dalam mempelajari materi tersebut. Adanya tanggung jawab individual, memotivasi siswa melakukan pekerjaan yang baik dan saling menjelaskan satu sama lain agar kelompok tersebut berhasil, keberhasilan akan tercapai jika seluruh anggota kelompok telah menuntaskan materi yang dipelajari.

Lima komponen utama atau tahapan dalam model pembelajaran kooperatif tipe STAD adalah presentasi kelas, kerja kelompok, kuis, peningkatan skor kuis individu, dan penghargaan kelompok. Pembelajaran konvesional dapat diartikan sebagai pembelajaran yang dilakukan umumnya oleh para guru selama ini dalam mengajarkan matematika. Dalam melaksanakan pembelajaran guru biasanya menggunakan format: teori-contoh-soal, dengan menjadikan guru sebagai pusat pembelajaran dan menggunakan langkah-langkah sebagai berikut: (1) Guru menyampaikan materi secara lisan (2) Guru mengadakan tanya jawab kepada siswa secara individual (3) Guru memberikan tugas kepada siswa secara individual 4). Secara bersama-sama membahas tugas (5) Guru dan murid menyimpulkan materi, dan (6) Pemberian evaluasi.

Perangkat pembelajaran merupakan perlengkapan kegiatan pembelajaran dibuat dan disusun secara sistematis yang digunakan oleh guru dalam proses pembelajaran. Perangkat pembelajaran yang efektif dan efisien juga dapat mengoptimalkan interaksi antara siswa dengan siswa atau siswa dengan guru selama kegiatan pembelajaran berlangsung. Perangkat pembelajaran yang dibuat dalam penelitian ini meliputi RPP (Rencana Pelaksanaan Pembelajaran), LKS (Lembar Kerja Siswa), dan THB (Tes Hasil Belajar Siswa). Perangkat pembelajaran yang baik adalah perangkat pembelajaran yang dapat menunjang pembelajaran sehingga tujuan yang diharapkan dalam pembelajaran dapat tercapai. Untuk menentukan perangkat yang baik diperlukan tiga kriteria yaitu: valid, praktis dan efektif. ${ }^{16}$ Sementara Arends mengatakan bahwa Pengajaran yang efektif membutuhkan individu-individu garis dasar yang mampu secara akademis, yang memiliki penguasaan mata pelajaran yang harus mereka ajarkan, dan yang peduli pada kesejahteraan anak-anak dan remaja. ${ }^{17}$ Ini juga membutuhkan individu yang dapat menghasilkan hasil, terutama yang dari prestasi akademik siswa dan pembelajaran sosial. Begitu pula dengan Hobri, menurutnya pembelajaran efektif terjadi apabila siswa secara aktif dilibatkan dalam pengorganisasian dan penemuan informasi (pengetahuan). Siswa tidak hanya secara pasif menerima pengetahuan yang diberikan guru, tetapi mereka dapat memberikan tanggapan secara aktif. ${ }^{18}$

Dari beberapa pernyataan di atas terlihat bahwa ada beberapa aspek yang mempengaruhi keefektifan pembelajaran, yaitu: penguasaan guru atas materi ajar, kepedulian guru terhadap siswa, ketuntasan belajar, respon siswa terhadap pembelajaran, dan ketersediaan waktu untuk pembelajaran. Sedangkan keefektifan pembelajaran dalam penelitian ini dapat ditinjau dari beberapa aspek, yaitu: kemampuan guru dalam mengelola pembelajaran, aktivitas siswa selama pembelajaran berlangsung, respon positif siswa terhadap pembelajaran, ketuntasan klasikal belajar siswa dan meningkatkan motivasi belajar siswa. Berdasarkan beberapa penelitian yang dilakukan oleh para peneliti terdahulu, pembelajaran kooperatif tipe STAD memiliki peran yang signifikan dalam membantu guru dalam melaksanakan pembelajaran yang lebih baik di kelas. Penelitian yang sama dengan peneliti banyak telah dilaksanakan, yakni Suprapti dengan hasil penelitian menunjukkan (1) Ketuntasan belajar secara klasikal 85,7\% siswa tuntas, (2) Aktivitas siswa efektif, (3) Kemampuan guru dalam mengelola pembelajaran baik, (4) Respons siswa terhadap pembelajaran positif. ${ }^{19}$ Hasil penelitian ini menunjukkan bahwa perangkat pembelajaran yang dikembangkan oleh Enny memenuhi kriteria perangkat pembelajaran yang baik untuk diterapkan dalam pembelajaran. Hal ini menjadi menarik untuk diteliti

${ }^{16}$ Kartianom Kartianom and Djemari Mardapi, "The Utilization of Junior High School Mathematics National Examination Data: Conceptual Error Diagnosis," REiD (Research and Evaluation in Education) 3, no. 2 (2018).

${ }^{17}$ Richard Arends, Classroom Instruction and Management (McGraw-Hill Companies, 1997).

${ }^{18}$ H Hobri, Metodologi Penelitian Pengembangan (Aplikasi Pada Penelitian Pendidikan Matematika) (Jember: Pena Salsabila, 2010).

${ }^{19}$ Endang Suprapti, "Pengembangan Perangkat Pembelajaran Matematika Model Kooperatif Tipe STAD Dengan Media Powerpoint Ispring Pada Materi Jajargenjang, Layang-Layang Dan Trapesium Di Kelas VII SMP," MUST: Journal of Mathematics Education, Science and Technology 1, no. 1 (2016): 57-68. 
dengan menggunakan model pengembangan pembelajaran menurut Thiagarajan, Semmel dan Semmel. Model ini dikenal dengan model Four-D models atau model 4-D. Model ini terdiri dari empat tahap, yaitu pendefinisian (define), perancangan (design), pengembangan (develop), dan penyebaran (disseminate).

\section{METODE}

Penelitian ini merupakan jenis penelitian pengembangan. Dalam penelitian ini yang akan dikembangkan adalah perangkat pembelajaran kooperatif tipe STAD pada materi faktorisasi suku aljabar. Perangkat pembelajaran yang akan dikembangkan dalam penelitian ini terdiri dari: rencana pelaksanaan pembelajaran (RPP), lembar kerja siswa (LKS), dan tes hasil belajar (THB). Pengembangan perangkat pembelajaran ini mengadopsi model 4-D dengan mengadaptasi dari Thiagarajan, Shemmel (1974:5) yang dilaksanakan dengan tiga tahap yaitu define (pendefinisian), design (perancangan), dan develop (pengembangan).

Populasi dalam penelitian ini adalah siswa kelas VIII MTs N Sumber Bungur Pamekasan, tahun ajaran 2015/2016 yang terdiri dari 9 kelas. Untuk uji keterbacaan perangkat pembelajaran yang meliputi LKS dan THB diambil sebanyak 3 orang siswa dengan kriteria 1 orang berkemampuan baik, 1 orang berkemampuan sedang dan 1 orang berkemampuan rendah, sementara untuk guru bidang studi hanya diambil satu orang. adapun untuk kelas uji coba perangkat pembelajaran dilakukan pada kelas VIII A, kelas kontrol diambil kelas VIII C dan kelas eksperimen diambil kelas VIII B.

Instrumen dan metode Pengumpulan Data dalam penelitian ini, yaitu: 1) lembar validitas perangkat pembelajaran untuk memperoleh data tentang penilaian para ahli terhadap perangkat pembelajaran terdiri dari lembar validitas RPP, lembar validitas LKS, dan lembar validitas THB, 2) lembar pengamatan kemampuan guru mengelola pembelajaran dan lembar pengamatan aktivitas siswa diperoleh melalui pengamatan yang dilakukan pengamat mulai dari kegiatan awal sampai menutup pelajaran selama empat kali pertemuan, 3) angket respon siswa, 4) angket motivasi belajar siswa, dan 4) THB dikumpulkan dari hasil pemberian tes.

Untuk menjawab pertanyaan penelitian yang kedua dan ketiga akan dilaksanakan penelitian eksperimen dengan ciri: (a) pemberian perlakuan, dimana diberikan perlakuan yang berbeda antara kelas eksperimen dan kelas kontrol, kelas eksperimen dilakukan pembelajaran kooperatif tipe STAD dan kelas kontrol dilakukan pembelajaran konvensional, (b) pengamatan terhadap gejala yang muncul pada variabel sebagai akibat pemberian perlakuan, dimana akan diamati apakah dengan adanya pemberian perlakuan akan mempengaruhi siswa, guru dan motivasi belajar dikelas, (c) pengendalian variabel lain bersama perlakuan yang ikut berpengaruh terhadap variabel tergantung. Karena tidak semua variabel dapat diamati dan dikontrol dengan baik maka penelitian ini termasuk dalam penelitian semu (quasi eksperiment), dimana dalam penelitian ini tidak semua variabel dapat dikontrol dengan ketat, misal kesehatan siswa, lingkungan keluarga, lingkungan masyarakat mereka bergaul dan lain sebagainya.

\section{HASIL DAN PEMBAHASAN}

\section{A. Proses dan Hasil Pengembangan Perangkat Pembelajaran}

Perangkat pembelajaran yang dikembangkan dalam penelitian ini adalah Rencana Pelaksanaan Pembelajaran (RPP), Lembar Kegiatan Siswa (LKS), dan Tes Hasil Belajar (THB). Berikut ini akan diuraikan pembahasan yang terkait dengan proses dan hasil pengembangan perangkat pembelajaran model kooperatif tipe STAD untuk materi faktorisasi suku aljabar.

1. Validasi Perangkat Pembelajaran

Sebelum melakukan ujicoba, perangkat pembelajaran model kooperatif tipe STAD untuk materi faktorisasi suku aljabar untuk kelas VIII SMP/MTs yang akan digunakan, dilakukan validasi terlebih dahulu. Validasi dilakukan agar perangkat pembelajaran yang dikembangkan layak digunakan untuk penelitian. Berdasarkan hasil penilaian validator terhadap perangkat pembelajaran yang dikembangkan berada dalam kategori valid dan dapat digunakan dengan sedikit revisi. Hal ini ditunjukan dengan penilaian validator terhadap RPP, LKS, dan THB minimal 3,00.

Pada tahap uji keterbacaan, ketiga siswa yang diminta untuk melakukan uji keterbacaan menyatakan bahwa secara umum mereka memahami kata atau kalimat yang ada di LKS, dan THB. Selanjutnya perangkat siap diujicobakan untuk mendapatkan data kualitas baik tidaknya perangkat pembelajaran, yaitu RPP, LKS, dan THB yang telah dikembangkan. 


\section{Kemampuan Guru Mengelola pembelajaran}

Sebelum pelaksanaan pembelajaran pada tahap ujicoba, peneliti berdiskusi dengan guru mitra dan mengadakan simulasi sebelum pembelajaran karena perangkat pembelajaran yang digunakan adalah pembelajaran model kooperatif tipe STAD yang merupakan model pembelajaran yang belum pernah diterapkan selama proses pembelajaran. Dengan melakukan diskusi dan simulasi, guru dapat lebih memahami pembelajaran yang akan digunakan dan peneliti juga dapat memberikan masukan kepada guru mitra.

Berdasarkan pengamatan kemampuan guru mengelola pembelajaran dengan hasil seperti pada Tabel 4.8, diketahui bahwa untuk setiap kriteria mempunyai rata-rata skornya di atas 3 atau setiap kriteria berada dalam kategori baik atau sangat baik. Berdasarkan data kriteria pengelolaan pembelajaran yang telah ditetapkan maka kemampuan guru dalam mengelola pembelajaran dikategorikan baik dalam kagiatan pembelajaran.

Pada kegiatan awal pelaksanaan pembelajaran di kelas, guru menyampaikan tujuan pembelajaran, memotivasi siswa dengan mengaitkan materi dengan konteks kahidupan siswa, mengingatkan kembali materi prasyarat atau materi yang pernah didapat, mengorientasikan siswa pada pembelajaran model kooperatif tipe STAD, menjelaskan cara pembentukan kelompok, dan menjelaskan cara menghitug skor perkembangan individu dan kelompok dengan menampilkan pada layar menggunakan LCD Proyektor. Pada fase penyajian informasi, sebelum guru menjelaskan tentang bentuk aljabar terlebih dahulu guru menampilkan slide tentang pengenalan aljabar.

Selanjutnya, guru memberikan kesempatan kepada siswa untuk bertanya, selanjutnya mengorganisasikan siswa ke dalam kelompok belajar. Pada kegiatan ini guru menampilkan nama-nama anggota kelompok dan memberikan arahan untuk berpindah kedalam kelompoknya. Setelah semua siswa berada dalam kelompoknya masing-masing, guru meminta siswa untuk menentukan pasangannya masing-masing dalam kelompok kemudian guru membagikan LKS dan memberikan arahan bagaimana cara kerja LKS serta meminta siswa untuk mengerjakan LKS secara berkelompok.

Setelah siswa selesai mengerjakan LKS secara berkelompok siswa diminta untuk mendiskusikannya dengan semua anggota kelompoknya masing-masing. Dengan belajar dalam kelompok, siswa akan memiliki kesempatan untuk mendapatkan hasil belajar yang lebih baik. Siswa yang belum bisa akan mendapatkan bantuan dari siswa yang sudah bisa, sedangkan siswa yang sudah bisa memiliki kesempatan untuk meningkatkan kemampuan akademiknya melalui peranannya sebagai tutor bagi temannya. Selama pengerjaan pada LKS berlangsung, guru berkeliling melihat aktivitas siswa dan membimbing siswa ketika siswa bertanya atau mengalami kesulitan. Bimbingan yang diberikan kepada siswa berupa langkah-langkah atau pertanyaan-pertanyaan yang mengarah pada penyelesaian masalah dalam LKS. Bimbingan yang dilakukan guru tersebut sesuai dengan teori scaffolding yang dikemukakan Vygotsky yaitu pemberian sejumlah bantuan kepada seorang anak selama tahap-tahap awal pembelajaran, kemudian menguranginya dan memberikan kesempatan kepada anak tersebut mengambil alih tanggung jawab yang semakin besar setelah ia dapat melakukannya sendiri. ${ }^{20}$ Bantuan tersebut dapat berupa petunjuk, pertanyaan, peringatan, atau dorongan ke arah pemecahan masalah.

Sebelum memberikan kuis, guru melibatkan siswa dalam membuat kesimpulan meskipun keterlibatan siswa masih terbatas. Guru memberikan kuis untuk dikerjakan secara individu. Pengumuman skor peningkatan individu dan kelompok disampaikan pada pertemuan selanjutnya sedangkan pemberian penghargaan kepada tim diberikan pada akhir pembelajaran disesuaikan dengan predikat yaitu tim super, tim hebat dan tim baik.

\section{Aktivitas Siswa}

Hasil penelitian tentang aktivitas siswa menunjukkan bahwa secara umum aspek aktivitas siswa untuk semua RPP berada pada interval kriteria batas toleransi waktu ideal. Sehingga aktivitas siswa selama pembelajaran kooperatif tipe STAD dapat dikategorikan baik. Dalam pembelajaran ini siswa dikelompokkan menjadi 8 kelompok. Kelompok yang terbentuk bersifat heterogen sesuai dengan kemampuan matematika dan jenis kelamin. Sebelum memulai mengerjakan LKS siswa berbagi tugas yang menjadi tanggung jawab setiap anggota kelompok. Sehingga dengan adanya diskusi kelompok siswa dapat belajar baik. Hal ini sesuai dengan salah satu prinsip pembelajaran Vygotski yaitu penekanan pada hakikat sosiokultural pada pembelajaran (the sociocultural of learning), yang artinya

${ }^{20}$ Nur, "Pemotivasian Siswa Untuk Belajar." 
siswa belajar melalui interaksi dengan orang dewasa dan teman sebaya yang lebih mampu. Bantuan belajar dari teman satu kelompok dapat menghilangkan kecanggungan antar siswa. ${ }^{21}$ Bahasa dari teman sebaya lebih mudah dipahami, selain itu siswa dapat dengan mudah mengungkapkan kesulitan-kesulitan yang dialami kepada teman sebaya karena mereka tidak merasa malu, enggan, maupun rendah diri kepada teman sebaya mereka. Oleh karena itu, diskusi dengan teman sebaya diharapkan dapat membuat siswa lebih aktif mengikuti kegiatan pembelajaran sehingga berakibat meningkatnya pemahaman siswa terhadap materi yang sedang dipelajari yang nantinya juga dapat meningkatkan hasil belajar siswa. Dalam pembelajaran ini, guru tidak memilih siswa untuk menjadi tutor, namun secara langsung siswa yang berkemampuan akademis tinggi membantu teman-teman sekelompoknya untuk menuntaskan tugas dalam LKS. Sehingga guru tidak menjadi satu-satunya sumber belajar dalam proses pembelajaran. Adapun aspek-aspek yang diamati meliputi mendengar/ memperhatikan penjelasan guru, bertanya kepada guru/menjawab pertanyaan guru, melakukan transisi ke kelompok belajar masing-masing (meliputi mengatur tempat duduk dan duduk dalam kelompok), bekerja dengan bantuan LKS meliputi (menerima, membaca LKS, dan mengerjakan LKS), berdiskusi dengan teman/guru (menanya, menyatakan pendapat, menanggapi pertanyaan, mengerjakan kuis, dan perilaku siswa yang tidak relevan dengan KBM.

Aktivitas siswa selama mengikuti pembelajaran terlihat ketika mereka sedang menyelesaikan masalah-masalah yang ada dalam LKS. Mereka sangat antusias dan saling bekerja sama antar anggota kelompoknya. Siswa yang lebih pintar akan mengajarkan temannya yang kurang, dan siswa yang kurang tidak segan untuk bertanya pada temannya. Selama empat kali pertemuan waktu yang paling banyak digunakan adalah pada fase membimbing kelompok bekerja dan belajar. Hal ini menunjukkan bahwa pembelajaran sudah memberikan kesempatan untuk menyelesaikan masalah/soal secara mandiri dengan cara diskusi kelompok, guru hanya sebagai fasilitator.

4. Respons Siswa terhadap Pembelajaran

Berdasarkan hasil analisis respons siswa, sebagian besar siswa memberikan respon positif terhadap setiap aspek yang direspons dan rata-rata persentase siswa yang memberi respons positif lebih dari $80 \%$. Hal ini mengindikasikan bahwa respon siswa terhadap perangkat dan kegiatan pembelajaran model kooperatif tipe STAD untuk materi faktorisasi suku aljabar termasuk kategori positif.

Berdasarkan hasil respon siswa terhadap pembelajaran model kooperatif tipe STAD tersebut, sebanyak 35 siswa dari 40 siswa yang berminat untuk mengikuti pembelajaran seperti ini lagi. Hasil ini menunjukkan bahwa siswa merasa senang dengan pembelajaran matematika dengan model kooperatif tipe STAD. Terlihat juga selama pembelajaran, siswa sangat antusias mengikuti pembelajaran dan berusaha untuk selalu aktif dalam pembelajaran.

Selain itu, siswa tampak bersemangat ketika guru mengorganisasikan mereka ke dalam kelompok-kelompok belajar dan meminta mereka mengerjakan LKS. Sebanyak 32 siswa sangat setuju dengan adanya diskusi kelompok karena belajar berkelompok dapat membantu dalam memahami dan menyelesaikan tugas atau soal. Selain itu sebagian besar siswa juga merasa senang dan tertarik terhadap LKS yang diberikan.

5. Hasil Belajar

Berdasarkan hasil analisis di Bab IV diperoleh bahwa ketuntasan yang dicapai siswa sebesar $85 \%$ yaitu dari 40 siswa 34 siswa tuntas belajar dengan nilai KKM 75 dan nilai rata-rata tes hasil belajar 82,45. Berdasarkan hasil tersebut dapat disimpulkan siswa telah mencapai ketuntasan secara individu dan ketuntasan belajar klasikal. Selain itu dari data yang diperoleh melalui tes hasil belajar (THB) dianalisis untuk memeriksa apakah THB yang dikembangkan telah memenuhi syarat validitas, reliabilitas, dan sentivitas. Proses perhitungan analisis-analisis tersebut selengkapnya terlampir.

Berdasarkan analisis data tes hasil belajar, didapat koefisen validitas butir soal terendah adalah 0,44 dan koefisien validitas butir soal tertinggi adalah 0,75 sehingga kategori validitas termasuk dalam kategori cukup atau tinggi. Jadi, butir soal THB tersebut telah valid karena koefisien validitas tiap butir soal lebih dari 0,40 sehingga dapat dikatakan bahwa tes hasil belajar ini sesuai dengan keadaan yang dievaluasi. Selain itu, diperoleh juga koefisien reliabilitas butir soal THB sebesar 0,51 sehingga butir soal THB tersebut telah reliabel karena koefisien reliabilitas termasuk kategori cukup. Jadi, tes hasil belajar ini dapat dipercaya karena memberikan hasil yang sama untuk subyek yang sama. Selanjutnya

\footnotetext{
${ }^{21}$ Nur.
} 
indeks sensitifitas butir soal terendah adalah 0,34 sehingga butir soal THB telah sensitif karena indeks sensitifitasnya lebih dari atau sama dengan 0,30 . Hasil tes hasil belajar siswa ini cukup peka dan mampu membedakan tingkat kemampuan siswa sebelum dan sesudah menerima pembelajaran. Dengan demikian, tes hasil belajar ini layak digunakan karena telah memenuhi kriteria valid, reliabel, dan sensitif.

\section{B. Hasil Eksperimen Perangkat Pembelajaran}

1. Kemampuan Guru Mengelola pembelajaran

Berdasarkan pengamatan kemampuan guru mengelola pembelajaran dengan hasil seperti pada Tabel 4.16, diketahui bahwa untuk setiap kriteria mempunyai rata-rata skornya di atas 3 atau setiap kriteria berapa dalam kategori baik atau sangat baik. Berdasarkan data kriteria pengelolaan pembelajaran yang telah ditetapkan maka kemampuan guru dalam mengelola pembelajaran dikategorikan baik dalam kagiatan pembelajaran. Setiap kegiatan guru pada tiap-tiap fase atau tahapan pembelajaran di kelas eksperimen disesuaikan dengan kegiatan pembelajaran pada RPP sebagaimana yang telah dilakukan pada kelas ujicoba.

2. Aktivitas Siswa

Hasil penelitian tentang aktivitas siswa pada kelas eksperimen menunjukkan bahwa secara umum aspek aktivitas siswa untuk semua RPP berada pada interval kriteria batas toleransi waktu ideal. Sehingga aktivitas siswa selama pembelajaran kooperatif tipe STAD dapat dikategorikan baik. Dalam pembelajaran ini siswa dikelompokkan menjadi 8 kelompok. Kelompok yang terbentuk bersifat heterogen sesuai dengan kemampuan matematika dan jenis kelamin. Sebagaimana aktivitas siswa pada kelas ujicoba, aktivitas siswa pada kelas eksperimen selama mengikuti pembelajaran terlihat ketika mereka sedang menyelesaikan masalah-masalah yang ada dalam LKS. Mereka sangat antusias dan saling bekerja sama antar anggota kelompoknya. Siswa yang lebih pintar akan mengajarkan temannya yang kurang, dan siswa yang kurang tidak segan untuk bertanya pada temannya.

3. Respon Siswa terhadap Pembelajaran

Berdasarkan hasil analisis respons siswa pada kelas eksperimen, sebagian besar siswa memberikan respon positif terhadap setiap aspek yang direspons dan rata-rata persentase siswa yang memberi respons positif lebih dari $80 \%$. Hal ini mengindikasikan bahwa respons siswa pada kelas implementasi terhadap perangkat dan kegiatan pembelajaran model kooperatif tipe STAD untuk materi faktorisasi suku aljabar termasuk kategori positif.

Berdasarkan hasil respon siswa terhadap pembelajaran model kooperatif tipe STAD tersebut, sebanyak 35 siswa dari 40 siswa yang berminat untuk mengikuti pembelajaran seperti ini lagi. Hasil ini menunjukkan bahwa siswa merasa senang dengan pembelajaran matematika dengan model kooperatif tipe STAD. Terlihat juga selama pembelajaran, siswa sangat antusias mengikuti pembelajaran dan berusaha untuk selalu aktif dalam pembelajaran.

Selain itu, siswa tampak bersemangat ketika guru mengorganisasikan mereka ke dalam kelompok-kelompok belajar dan meminta mereka mengerjakan LKS. Sebanyak 34 siswa sangat setuju dengan adanya diskusi kelompok karena belajar berkelompok dapat membantu dalam memahami dan menyelesaikan tugas atau soal. Selain itu sebagian besar siswa juga merasa senang dan tertarik terhadap LKS yang diberikan.

4. Hasil Belajar

Berdasarkan hasil analisis di Bab IV diperoleh bahwa ketuntasan belajar yang dicapai siswa di kelas eksperimen sebesar 82,5\% yaitu dari 40 siswa, 33 siswa tuntas belajar dengan nilai KKM 75 dan nilai rata-rata tes hasil belajar 80,48 . Berdasarkan hasil tersebut dapat disimpulkan siswa telah mencapai ketuntasan secara individu dan ketuntasan belajar klasikal.

5. Motivasi Belajar

Berdasarkan hasil analisis motivasi belajar siswa pada kelas VIII B menunjukkan motivasi belajar siswa sebelum penggunaan model pembelajaran kooperatif tipe STAD sebesar $74,58 \%$ dan setelah penggunaan model pembelajaran kooperatif tipe STAD sebesar $84,90 \%$. Hal ini menunjukkan adanya peningkatan motivasi belajar siswa dari pembelajaran sebelumnya dengan pembelajaran yang dilakukan dengan menggunakan model STAD sebesar 0,41 dengan kategori sedang. Sedangkan hasil analisis motivasi belajar siswa untuk kelas kontrol yaitu pada kelas VIII C sebelum penggunaan model pembelajaran konvensional sebesar $82,42 \%$ dan setelah penggunaan model pembelajaran konvensional sebesar $85,52 \%$. Hal ini menunjukkan adanya peningkatan motivasi belajar siswa sebesar 0,18 dengan 
kategori rendah. Hal ini menunjukkan bahwa motivasi belajar siswa dengan menggunakan model pembelajaran kooperatif tipe STAD lebih baik dari motivasi belajar siswa menggunakan model pembelajaran konvensional.

\section{SIMPULAN DAN SARAN}

\section{Simpulan}

Berdasarkan hasil penelitian diperoleh kesimpulan sebagai berikut: alur dalam pengembangan perangkat dalam penelitian ini telah mengacu pada model pengembangan yang dilakukan Thiagarajan (four D models) yang sudah dimodifikasi dan disederhanakan. Modifikasi yang dilakukan adalah istilah analisis konsep diganti dengan analisis materi dan analisis konsep yang semula paralel dengan analisis tugas diubah menjadi berurutan dari analisis materi ke analisis tugas. Sedangkan Penyederhanaan model yang dilakukan dari empat tahap menjadi 3 tahap, yaitu : pendefinisian (define), perancangan (design), dan pengembangan (develop). Karena pada tahap ini sudah menjawab pertanyaan penelitian yang pertama. Sedangkan untuk menjawab pertanyaan penelitian kedua, perangkat yang sudah dinyatakan baik kemudian diimplementasikan. Pengembangan ini dimulai dari analisis awal akhir, analisis siswa, analisis materi, analisis tugas dan spesifikasi tujuan pembelajaran. Berdasarkan analisis tersebut dirancang suatu perangkat pembelajaran pada materi faktorisasi suku aljabar yang mengacu pada model pembelajaran kooperatif tipe STAD. Perangkat pembelajaran yang telah disusun kemudian dikembangkan dengan cara divalidasi oleh ahli, direvisi berdasarkan saran dari validator, dilakukan uji keterbacaan dan dilakukan ujicoba lapangan di kelas. Dari hasil pengembangan diperoleh perangkat pembelajaran yang baik. Kemudian dilakukan ekperimen terbatas untuk melihat apakah perangkat tersebut lebih baik dari pembelajaran konvensional khususnya pada motivasi belajar siswa. Perangkat pembelajaran yang dihasilkan berupa: Rencana pelaksanaan Pembelajaran (RPP), lembar Kerja Siswa (LKS), dan Tes Hasil Belajar (THB).

Dari hasil analisis deskriptif data hasil validasi, dan data hasil ujicoba diperoleh bahwa perangkat pembelajaran kooperatif tipe STAD untuk materi faktorisasi suku aljabar di kelas VIII MTs N Sumber Bungur Pamekasan memenuhi kualitas baik, sebab syarat-syarat kualitas baik suatu perangkat pembelajaran dalam penelitian ini telah dipenuhi antara lain sebagai berikut. Valid, karena hasil validasi ahli pada RPP untuk setiap aspek mempunyai nilai rata-rata skor total validasi 4,46 atau setiap kriteria berada dalam kategori baik atau sangat baik, hasil validasi pada LKS setelah revisi untuk setiap aspek mempunyai nilai rata-rata skor total validasi 4,36 atau setiap kriteria berada dalam kategori baik atau sangat baik. Hasil validasi untuk THB untuk setiap aspek mempunyai nilai rata-rata skor total validasi 4,37 atau setiap kriteria berada dalam kategori sangat baik. Praktis, karena dari analisis data kemampuan guru mengelola pembelajaran untuk setiap aspeknya mempunyai nilai rata-rata minimal 3,00 atau setiap kriteria dalam kategori baik atau sangat baik dan analisis data aktivitas siswa dalam kegiatan pembelajaran sesuai dengan alokasi waktu ideal dengan toleransi $10 \%$. Efektif, karena respon siswa positif dan hasil belajar tuntas secara klasikal. Tes Hasil Belajar (THB) memenuhi kriteria valid, reliabel dan sensitif.

Dari hasil analisis data hasil implementasi perangkat pembelajaran diperoleh bahwa perangkat pembelajaran yang telah dikembangkan efektif untuk mengajarkan materi faktorisasi suku aljabar di kelas VIII MTs. N Sumber Bungur Pamekasan, sebab telah memenuhi syarat, yaitu kemampuan guru mengelola pembelajaran untuk setiap aspeknya mempunyai nilai rata-rata minimal 3,00 atau setiap kriteria dalam kategori baik atau sangat baik: data aktivitas siswa dalam kegiatan pembelajaran sesuai dengan alokasi waktu ideal dengan toleransi $10 \%$. Artinya aktivitas siswa dalam pembelajaran efektif; respon siswa terhadap perangkat dan kegiatan pembelajaran positif; ketuntasan belajar secara klasikal mencapai lebih dari 80\%; dan ada peningkatan motivasi belajar siswa sebesar 0,41 dengan kategori sedang.

Dari hasil analisis data eksperimen perangkat pembelajaran diperoleh bahwa perangkat pembelajaran kooperatif tipe STAD lebih baik dari pembelajaran konvensional di kelas VIII MTs. N Sumber Bungur Pamkasan, sebab telah memenuhi syarat, yaitu ketuntasan belajar secara klasikal pada kelas eksperimen mencapai 82,5\% sedangkan ketuntasan belajar secara klasikal pada kelas kontrol hanya mencapai 61,54\%: dan motivasi belajar siswa pada kelas eksperimen meningkat sebesar 0,41 dengan kategori sedang, sedangkan motivasi belajar siswa pada kelas kontrol meningkat hanya sebesar 0,18 dengan kategori rendah. 


\section{Saran}

Secara keseluruhan, pembelajaran yang telah diterapkan pada siklus I dan siklus II sudah baik, hanya sajamasih perlu banyak pengembangan, karena teknologi informasi tidak cukup sampai disitu saja. Masih banyak pengembangan yang lebih inovatif dan kreatif. Untuk guru, dituntut untuk lebih aktif dalam mengikuti berbagai pelatihan teknologi pendidikan, agar bisa lebih maksimal dalam penerapan media pembelajaran berbasis teknologi informasi.

\section{DAFTAR PUSTAKA}

Amri, Sofan. Pengembangan Dan Model Pembelajaran Dalam Kurikulum 2013. Jakarta: Prestasi Pustaka, 2013.

Apino, Ezi. "Meningkatkan Toleransi Siswa Dalam Pembelajaran Matematika Melalui Penerapan Model Guided Discovery Setting Pembelajaran Kooperatif Tipe Think Pair Share," 2016.

Arends, Richard. Classroom Instruction and Management. McGraw-Hill Companies, 1997.

Hobri, H. Metodologi Penelitian Pengembangan (Aplikasi Pada Penelitian Pendidikan Matematika). Jember: Pena Salsabila, 2010.

Indonesia, Presiden Republik. Undang-undang Republik Indonesia nomor 20 tahun 2003 tentang sistem pendidikan nasional, Pub. L. No. 20, 79 (2003).

Isjoni, H. Cooperative Learning. Bandung: Alfabeta, 2009.

Kartianom, K, and Heri Retnawati. "Why Are Their Mathematical Learning Achievements Differents? Re- Analysis TIMSS 2015 Data In Indonesia, Japan, and Turkey." International Journal on New Trends in Education and Their Implications 9, no. 2 (2018): 33-46.

Kartianom, Kartianom, and Djemari Mardapi. "The Utilization of Junior High School Mathematics National Examination Data: Conceptual Error Diagnosis." REiD (Research and Evaluation in Education) 3, no. 2 (2018).

Langgulung, Hasan. Manusia Dan Pendidikan: Suatu Analisa Psikologi, Filsafat Dan Pendidikan. Al Husna Zikra, 1995.

Nur, Moh. "Pemotivasian Siswa Untuk Belajar." Surabaya: University Press-Universitas Negeri Surabaya, 2001.

Retnawati, Heri, Hasan Djidu, Ezi Apino, Kartianom Kartianom, and Risqa D Anazifa. "Teachers' Knowledge about Higher-Oeder Thinking Skills and Its Learning Strategy." Problems of Education in the 21st Century 76, no. 2 (2018).

Schunk, Dale H. Learning Theories an Educational Perspective Sixth Edition. Pearson, 2012.

Slavin, Robert E. Psikologi Pendidikan Teori Dan Praktik. Jakarta: Indeks, 2011.

Suprapti, Endang. "Pengembangan Perangkat Pembelajaran Matematika Model Kooperatif Tipe STAD Dengan Media Powerpoint Ispring Pada Materi Jajargenjang, Layang-Layang Dan Trapesium Di Kelas VII SMP.” MUST: Journal of Mathematics Education, Science and Technology 1, no. 1 (2016): 57-68.

Tiro, Muhammad Arif. Cara Efektif Belajar Matematika. Makassar: Andira Publisher, 2010.

Wijayanti, Indra Kusuma, and Heri Retnawati. "Pengembangan Bahan Ajar Dengan Pendekatan Kontekstual Model Pembelajaran Active Joyful Effective Leraning Pada Materi Segiempat Dan Segitiga Kelas VII Untuk Meningkatkan Kemampuan Komunikasi Matematis Siswa.” Jurnal Pendidikan Matematika-S1 6, no. 7 (2017): 73-83. 